See discussions, stats, and author profiles for this publication at: https://www.researchgate.net/publication/354602571

\title{
Video scribing as a new marketing tool for educational institutions
}

Article · September 2021

DOI: 10.24115/S2446-6220202173A1469p.599-607

\section{CITATIONS}

0

4 authors:

Halyna Horbenko

Borys Grinchenko Kyiv University

22 PUBLICATIONS 1 CITATION

SEE PROFILE

Leonid Novokhatko

Borys Grinchenko Kyiv University

3 PUBLICATIONS OCITATIONS

SEE PROFILE
READS

79

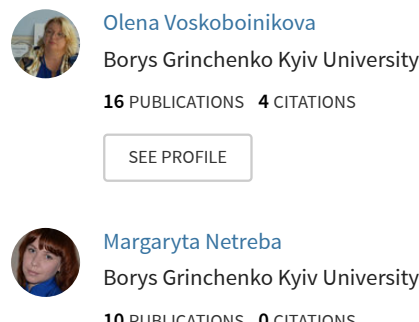

10 PUBLICATIONS OCITATIONS

SEE PROFILE

Some of the authors of this publication are also working on these related projects:

THE DESIGN AND USE OF THE OPEN CLOUD BASED LEARNING AND RESERCH ENVIRONMENT OF A UNIVERSITY View project

Цифрова культура View project 


\section{VIDEO SCRIBING AS A NEW MARKETING TOOL FOR EDUCATIONAL INSTITUTIONS}

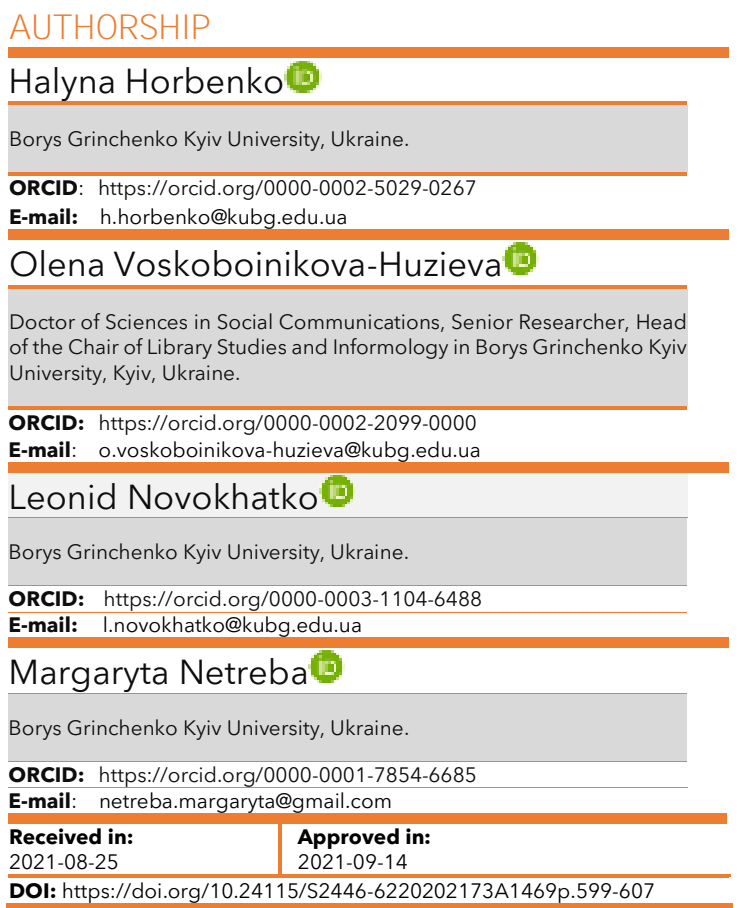

\section{INTRODUCTION}

The modern information environment is in digital and visual growth when the visual reality is full of information created with a help of different visual techniques and technologies. Experts have proclaimed that we have entered the video era, which is the next step after picture-and-text. As such, a main trend in 2020 was the increased time spent watching online videos. Official statistics confirm this fact. In 2019 average time spent watching digital video each day rose to just under 100 minutes. That is a whole hour and 40 minutes each day, dedicated to watching videos on social media platforms like YouTube and videos on company websites, in emails, and adverts. eMarketer data predicts that this will rise to over 108 minutes each day during 2020 and continue to increase into 2021 (LINFORD, 2020). The wide popularity of the variety of video content has captured the attention of many companies and brands because this type of video communication with a target audience is regarded as an effective channel in modern internet marketing. As such, video content has many variants, including whiteboard animation videos and video presentations.

Whiteboard animation videos, also known as scribe videos, are actively used for advertising, social, and educational aims by such large corporations as Coca-Cola and Google. Scribe videos are currently very popular because of their original and unique manner of presentation. Similar to cartoons, they are simple, yet dynamic. With the help of a scribe video, it is easy to explain complicated information about a company or a product to an audience in a clear and accessible way in a matter of a few minutes.

\section{LITERATURE REVIEW}

The basis of video scribing is a model that consists of two communication channels: visual and audio. While an audience does not always comprehend the words they hear, a parallel visualization of those words helps viewers understand them. A picture-text-voice combination permits clear visualization and the ability to explain complicated ideas in a simple way (PETROVSKIY, 2016). The scribe video format helps pique the interest of viewers and maintain their attention with the help of a presence effect. Viewers feel that a story is being created before their eyes. In addition, viewers do not passively watch such videos; with each passing second, they try to guess what will happen next.

Video scribing is not simply an interesting and persuasive means of transferring informationit is also inexpensive because the scribe video creation process is more cost-effective than the traditional video-making process. This is one reason why video scribing has become so popular for companies, charitable organizations, and educational institutions. It is used for business concept presentations, advertisement of products and services, creation of educational material, training, and masterclasses. It is also used as an effective tool for sessions, conferences, meetings, internal communication, and coaching. Moreover, companies can choose from various types of video scribing products depending on their goals and tasks. Different products can create an invitation, a presentation, instructions, a compendium of lectures, a viral video, a mental map, visual notes, a business drawing, or a story. 
Specialized programs for video scribing can be divided into two functional groups: image creation and editing of scribe videos from those images. The most popular programs for image creation are ScribMaster, HandWrite PRO, and Adobe Illustrator. To create a scribe video by editing original or basic images, programs such as VideoScribe, Explain Everything, Easy Sketch, and PowToon can be used.

In recent years, video scribing has been used by institutions of higher learning as an additional educational tool. Dr. R. Wiseman, professor of psychology at Hertfordshire University, has demonstrated that studying with scribe videos allows students to remember $15 \%$ more information than they could retain from a typical lecture (PARK, WISEMAN, 2018). Likewise, modern institutions of higher learning actively use popular video formats, such as video scribing, to expand opportunities for bilateral communication with a target audience. For example, Borys Grinchenko Kyiv University uses scribe videos to popularize educational projects, introduce new educational programs to applicants, social work of higher education school, and share entertaining educational content. Scribe videos are also used as an information and reporting channel for teachers. In short, these videos are a versatile tool to realize a marketing strategy.

Much research has shared information about the advantages of multimedia tools in the educational process. For example, an article by Artal-Sevil, Romero, and Artacho (2018) underlined the advantages of multimedia tools such as Prezi, Emaze, Knovio, Haiku Deck, Slidebean, Canva, Google Slides, VideoScribe, PowToon, and Sway. The authors concluded that these tools are effective for educational activities because, with these programs, it is possible to create dynamic animations, presentations, and multimedia resources.

Researchers Chiriacescu, Chiriacescu, Miron, and Barna (2020) demonstrated the effectiveness of "animation boards" for explaining difficult theories in physics. The result is a several-second video that has access to the student's visual and auditory stimuli. Thus, the students take an active part in the educational process and the learning material's level of difficulty becomes higher.

The topic of "animation board" using effectiveness comes into focus in the article by Suhroh, Cahyono, Astuti (2020). The research describes the effect of "animation board" used in English language project learning ( $\mathrm{PjBL}$ ) in Indonesian professional secondary schools. The research results show that the students who study language with animation boards inPjBLlearn more information than those students who learn the language with a help of standard mass mediatools. Students' creativity level (little-c andmini-c) has no effect on their English-language presentation skills. The conclusion regarding material learning level using Sparkol, the video materials for Indonesian writing skills upgraded for primary school students have been published in the publication by Sofiya, Yulianto, Hendratno (2018).

Espino, Suarez, Gonzalez-Henriquez (2020) study the digital video used in the education system of secondary schools and universities, where teachers provide educational technologies. The results show that secondary school teachers use video materials more often. They are more innovative than university teachers. A specialized module based on analyzed materials includes articles about marketing and branding in the higher education system. They describe the experience of education institutions in Australia, Greece, Ecuador, Russia, Poland, and Ukraine.

An example of the higher education system and integration of visual culture in Australia is an article by Gottschall, Saltmarsh (2017), which analyzes promotional videos on the websites of Australian universities as their branding and marketing forms. The authors underline multimedia texts which are illustrations of students' lifestyles, their features, goals, and desires. Favaloro (2015) analyzes the marketing investment models of the universities and the level of students' number increasing as the result of the marketing investments under projecting government-funding reductions in Australian universities.

The experience of the Republic of Greece in marketing communication with potential applicants is shown in the article by Gunina, Komarkova, Pribyl (2019). The research focuses on the study of university advertising campaign schedules in the chosen mass media. It also is aimed at the analysis of advertising strategies in private and public universities. And the study of synergies between advertising activities and several future students. The authors underline 
that there is a difference in the advertising strategies of private and public universities. There is a positive correlation between their advertising activities and the number of future students.

The aim of the publication by Medina-Chicaiza, Garcia-Garcia, Jarrin-Arias (2019) is a proposal for education product and service promotion with Bluetooth direct marketing. The research was held at the Technical University of Ambato-Ecuador.

The general trends of new social media branding strategies (without the accent on the education sphere) are described in the article by Fournier, Avery (2011). The authors study a new cultural area with the open code in branding. They also describe new (for that time) marketing strategies aimed at the active involvement of internet users.

The article by Vetrova, Kabanova, Medvedeva, Jukova (2019) describes the main tools of education service promotion in Russian State Social University: mass media advertising, outdoor advertising, fairs and exhibitions, open doors days, master-classes, round tables, conferences, workshops, internet advertising, social media, social media groups, and communities and the university website.

There is an analysis of communication tools in internet marketing of higher education institutions (in Poland and Ukraine) in the article by Kisiolek, Karyy, Halkiv (2021). The scientists underline that the focus on the intake of students in higher education institutions is universal for all countries and has no significant differences in internet communication tools use. University marketing managers use internet advertising tools widely, but they find it difficult to use PR tools and product promotions. Internet marketing communication is an important part of marketing strategies in higher education institutions.

But the topic of video scribing as a tool of marketing strategies for an educational program popularization has not been an object of special studying in modern scientific researches.

\section{METHODS}

Such methods as theoretical analysis of the scientific and methodical literature were used in the article to getting functional and communication features of the video scribing; systematization, and aggregation of the empirical results of the research to University's image assessing and formation of positive social opinion about the education services. It also used static analytical methods for analyzing the effectiveness and audience coverage through view and like data of Borys Grinchenko Kyiv University video scribing series.

The empirical basis for the research is video scribing series of Borys Grinchenko Kyiv University shared on the official social platforms of the higher education institution.

Content features: 60-180-second original videos.

Content variety: educational program presentations, educational instructions, social video notes, video invitations to educational events.

Target audience: 16-21-year-old young people who plan to study in a higher education institution.

Duration of the research: May 2017- May 2020.

The total number of scribe videos shared by the university during the period is 27 .

\section{RESULTS}

Borys Grinchenko Kyiv University has broadened the scope of video scribing through making and sharing different types of video scribing products on different platforms. The aim of this effort is to share complete, open, and current information about the university and its educational and professional programs with the target audience. It was also intended to support the university's positive image, social opinion formation, and generation of interest in popular professions among applicants and the wider society.

The article illustrates the material mentioned above with examples of video scribing as a tool of educational programs and project presentations at Borys Grinchenko Kyiv University. 
Among the scribing products in this research are video presentations of new educational programs, such as E-studying Management, International Journalism, Applied Mathematics, Information, Library and Archive Services, Romance Language and Literature, and Digital Project Content Production. Also included are master's programs at the Journalism Institute. We should note that each video is the work of teams of teachers and students in the Competencies Centers of Borys Grinchenko Kyiv University.

The article shows the conformity of video scribing creation steps, professional roles and work processes in the Competencies Centers.

Table 1. Conformity of video scribing creation steps, professional roles, and work process in Competence Centers

\begin{tabular}{|c|c|c|}
\hline Creation Steps & Professional Roles in the team & Competence Centers \\
\hline $\begin{array}{l}\text { Idea, conception, and stylistics } \\
\text { development }\end{array}$ & $\begin{array}{l}\text { Advertising Specialist, Creative } \\
\text { Strategist }\end{array}$ & Modern Communication Center \\
\hline Unique script creation & Copywriter, Screenwriter & Modern Communication Center \\
\hline Drawing of main scenes & Illustrator, Art Director & Multimedia Technology Center \\
\hline Creation of characters & Illustrator & Multimedia Technology Center \\
\hline Musical accompaniment & Sound Engineer, Cameraman & Tele Journalism Workshop \\
\hline Voice-over & Announcer, Sound Engineer & Radio BG Workshop \\
\hline Editing & Motion Designer, Scriber & Astudia Tele Journalism Workshop \\
\hline Movie release and promotion & Advertising Specialist, PR Specialist & Multimedia Technology Center \\
\hline
\end{tabular}

Source: Search data.

The program VideoScribe was chosen for video creation. This program contains a large library of pictures, a music gallery, and a voice recording function (VIDEOSCRIBE, 2020). Users can export the main projects onto social media pages or their YouTube channels.

The main channels for interaction between Borys Grinchenko Kyiv University and the target audience are a corporative website, the official Facebook and Instagram pages, and a YouTube channel. The web analysis data were used in the research to generate statistical data about video scribing outreach on the different platforms. The timeline was May 2017-May 2020.

Figure 1. The level of audience motivation to interact with video scribers of Borys Grinchenko Kyiv University educational programs

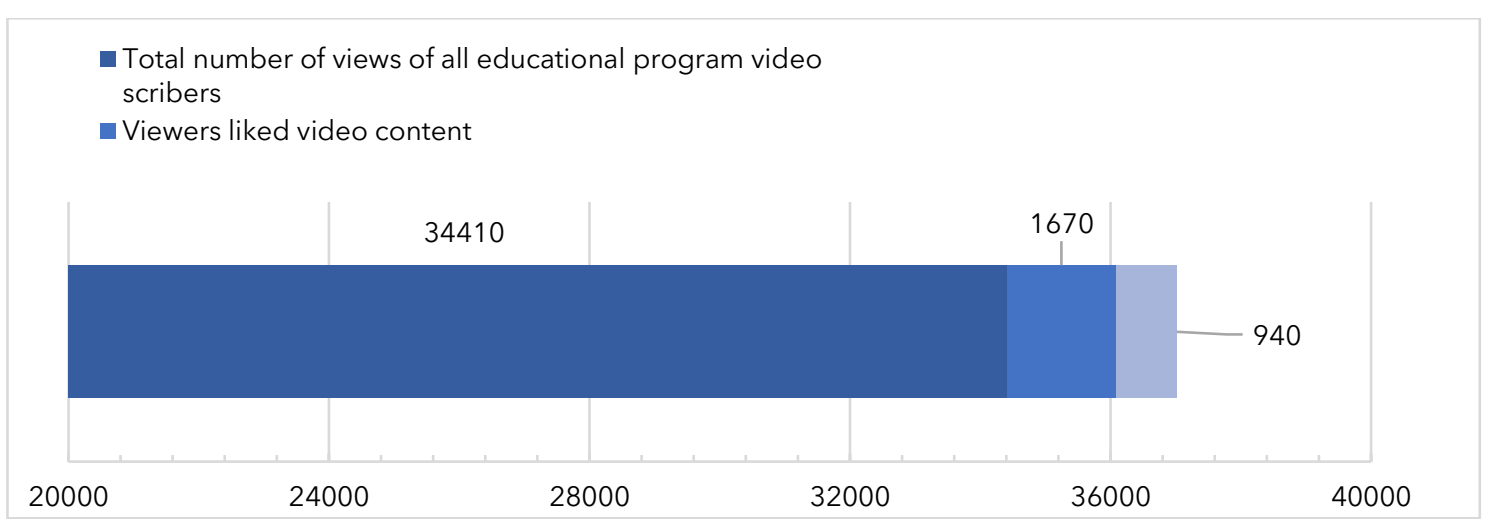

Source: Search data.

The next type of scribing product considered in the research is video instruction, including the video scribes for applicants, "Quota-3" and "Creative Credit," and the video scribe for students, "Tablet." The video scribe "Creative Credit" should be highlighted because it was shared through the internet channels of Borys Grinchenko Kyiv University and was used in external advertising (e.g., on TV screens in Hyundai trains). 
The 30-day advertising campaign outreach was viewed by 156,000 passengers (through 3360 airings on 540 screens). These numbers are supplemented by web analysis data about internet outreach, as shown in Figure 2.

Figure 2. The level of audience motivation to interact with video scriber instructions for applicants and students

- Total number of views of all video scriber instructions

- Viewers liked video content

18200

2270

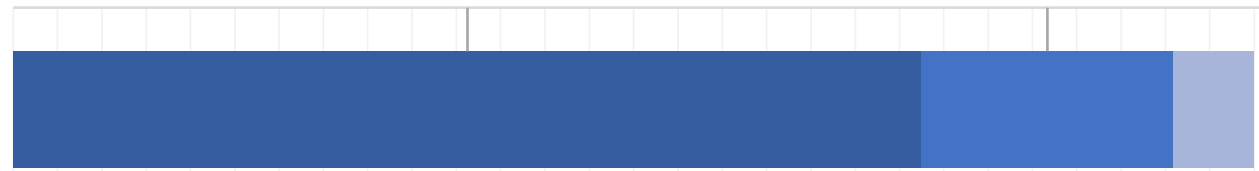

\section{Source: Search data.}

Attention must also be paid to the video scriber series for the popularization of experimental education efforts in primary schools. This series, named "Primary School: Education and Life," was implemented under the brand of Borys Grinchenko Kyiv University. Thirteen animated products were created, including a promotional video for first-graders' parents, a video for teachers working with this innovative program for primary schools, and eleven videos covering information about work-books on the topics: "I am a Schoolboy; I am a Schoolgirl," "My School Bag," "The Life of a Book," "On the Way to School," "Playground," "Our School Is Our Home," "The Laws of School Country," "The School of Polite Children," "Growing Up Healthy," "Beautiful and Useful," and "School Year" (NETREBA, 2020).

Public knowledge of the project "Primary School: Education and Life" has increased with the help of video scribing products. The total number of views for these videos is more than 15,000 and there are about 100 articles about the project in different media outlets. The number of supporters has also increased as more and more people want to take part in the realization of this project.

The total number of video scriber views on social media is about 68,000 , confirming that video scribing technology has been an effective tool for realization of the marketing strategy of the Borys Grinchenko Kyiv University. This effectiveness is demonstrated by the results of the entrance campaign of the university in 2020. For example, according to data from the Journalism 061 specialty, 3,600 applications were submitted for 225 licensed places, about 100 applicants for each state-funded place. According to statistics from the Integrated State Digital Data of Educational Questions, Borys Grinchenko Kyiv University is a leader among Ukrainian universities in the number of applications to this specialty.

\section{DISCUSSION}

The use of video scribing for popularization of educational programs and projects remains a debatable issue as scientists direct significant attention towards video scribing and consider it as an interactive educational tool in their research. Analysis of the collected material allows scientists to directly study scribing as a marketing communication tool. It could also be an effective tool for scientific teachers' and tutors' work if used as business scriber-cards or visual lecture and conference notes. 


\section{CONCLUSION}

The results of the research on Borys Grinchenko Kyiv University prove that video scribing technology can be a new tool for marketing strategy as a type of multimedia content that provides an interactive link between the university and the target audience.

The following conclusions were formulated from this research:

- Video scribing is a visualization tool that can be an alternative to traditional advertising, especially for companies with a minimal budget.

- Scribe videos can keep the focus of the target audience for a long time because of the sensed-presence effect; viewers feel that the story is being created before their eyes.

- Video scribing involves the audience in the live story as the viewers are not passive but instead try to guess what happens next.

- Scribe videos provoke positive emotions and interest because they are simple, showy, and similar to cartoons. They also can be watched many times, an effective element in involving the target audience.

The case of Borys Grinchenko Kyiv University proves that video scribers can be a creative part of a marketing strategy for educational institutions to maintain a positive image and form public opinion about popular professions among applicants. Future research should focus on specific examples of video scribers where the scribers are effective tools for marketing strategies. It is also important to popularize this tool in the education sector.

\section{REFERENCES}

ANDROSHCHUK, I. V.; ANDROSHCHUK, I. P. Scribing as a means of enhancing the educational process in secondary school. Information Technologies and Learning Tools, 2019, 72 (4), p. 67-80. Available at : https://doi.org/10.33407/itlt.v72i4.2602. Access: June $21,2021$.

ARTAL-SEVIL, J. S.; ROMERO, E.; ARTACHO, J. M. Using new multimedia learning technologies: presentations design tools, dynamic animations, interactive maps, visual content and multimedia resources. In L. CHOVA, G.; MARTINEZ, A. L.; TORRES, I. C. (Eds.), Edulearn 18: 10th International Conference on Education and New Learning Technologies, 2018, p. 9617-9627. Available at: https://www.researchgate.net/publication/326713474 _USING_NEW_MULTIMEDIA_LEARNING_TECHNOLOGIES_PRESENTATIONS_DESIGN_TOO LS_DYNAMIC_ANIMATIONS_INTERACTIVE_MAPS_VISUAL_CONTENT_AND_MULTIMEDIA_ RESOURCES. Access: June 21, 2021.

BELOUSOVA, L.; ZHITENEVA, N. Visualization of learning material using technologies of skribing in teachers' profession alactivities. Physics and Mathematics Education: scientific journal, 2016, Issue 1 (7), p. 39-47.

CHIRIACESCU, B.; CHIRIACESCU, F. S.; MIRON, C.; BARNA, V. Whiteboard Animation - A Tool for Teaching the Special Theory of Relativity. In LUNGU, M.; POPESCU, A.; . SPOREA, C. (Eds.), Tim 19 Physics Conference, 2020, Vol. 2218. Available at : https://doi.org/10.1063/5.0001535. Access: June 21, 2021.

ESPINO, J. M. S.; SUAREZ, M. D. A.; GONZALEZ-HENRIQUEZ, J. J. Video for teaching: classroom use, instructor self-production and teachers' preferences in presentation format. Technology Pedagogy and Education, 2020, 29 (2), p. 147-162. Available at : https://doi.org/10.1080/1475939x.2020.1726805. Access: June 21, 2021.

FAVALORO, C. Marketing in the Australian higher education sector. Journal of Higher Education Policy and Management, 2015, 37 (5), p. 490-506. Available at : https://doi.org/10.1080/1360080x.2015.1079396 Access: June 21, 2021.

FOURNIER, S.; AVERY, J. The uninvited brand. Business Horizons, 2011, 54 (3), p. 193-207. Available at : https://doi.org/10.1016/j.bushor.2011.01.001. Access: June 21, 2021. 
FRANCH, E. B.; PEYRO, C. F. Outdoor advertising in the university classroom: a methodology of innovation through practice. In CHOVA, L. G.; MARTINEZ, A. L.; TORRES, I. C. (Eds.), Inted2014: 8th International Technology, Education and Development Conference, 2014, p. 2203-2209.

GOTTSCHALL, K.; SALTMARSH, S. "You're not just learning it, you're living it!' Constructing the "good life' in Australian university online promotional videos. Discourse-Studies in the Cultural Politics of Education, 2017, 38 (5), p. 768-781. Available at : https://doi.org/10.1080/01596306.2016.1158155 Access: June 21, 2021.

GUNINA, D.; KOMARKOVA, L.; PRIBYL, V. How to attract university applicants: exploring tertiary education advertising patterns in the Czech Republic. Tertiary Education and Management, 2019, 25 (4), p. 349-366. Available at : https://doi.org/10.1007/s11233-01909038-9. Access: June 21, 2021.

KISIOLEK, A.; KARYY, O.; HALKIV, L. The utilization of Internet marketing communication tools by higher education institutions (on the example of Poland and Ukraine). International Journal of Educational Management. Available at : https://doi.org/10.1108/ijem-07-20200345. Access: June 21, 2021.

LINFORD, N. 5 Video marketing trends you need to know for 2020, 2020. Available at: https://blog.videoscribe.co/5-video-marketing-trends-you-need-to-know-for-2020. Access: June 21, 2021.

MADLENAK, R.; MADLENAKOVA, L.; RUDAWSKA, A. VIRAL MARKETING AS PART OF EFFECTIVE UNIVERSITY MARKETING STRATEGY. In L. G. Chova, A. L. Martinez, \& I. C. Torres (Eds.), Inted2017: 11th International Technology, Education and Development Conference, 2017, p. 5629-5634. Available at : https://www.researchgate.net/publication/315352452 _VIRAL_MARKETING_AS_PART_OF_EFFECTIVE_UNIVERSITY_MARKETING_STRATEGY. Access: June 21, 2021.

MEDINA-CHICAIZA, R.; GARCIA-GARCIA, J.; JARRIN-ARIAS, J. Proximity marketing: a tool for the promotion of educational products or services. 3c Empresa, 2019, 8 (2), p. 45-67. Available at : https://doi.org/10.17993/3cemp.2019.080238.44-67 Access: June 21, 2021.

NETREBA, M. Promotion of educational project using tools of visual communication (on the example of the project "primary school: education for life". Journal State and Regions Series Social Communications, 2020, 2 (42), p. 122-126. (In Ukrainian). Available at : http://doi.org/10.32840/cpu2219-8741/2020.2(42).18 Access: June 21, 2021.

PARK, A.; WISEMAN, R. The RSA Animate Revolution, 2018. Available at : https://www.youtube.com/watch?timecontinue=83v=HwN7P2048R0. Access: June 21, 2021.

PETROVSKYI, P. Scribing. It is easy to explain, 2016, 208p. Moscow (In Russian). Available at: https://www.livelib.ru/. Access: June 21, 2021.

SOFIYA, A.; YULIANTO, B.; HENDRATNO. The Development of Sparkol Videoscribe Based Internet Learning Media in Improving Writing Skills of Indonesian Language for Elementary School Students. In DEMPSEY, H.; SRIBOONRUANG, O.; SUMINTONO, B. et al. (Eds.), Proceedings of the 2nd International Conference on Education Innovation, 2018, Vol. 212, p. 108-111. Available at: https://www.atlantis-press.com/proceedings/icei-18/55907458. Access: June 21, 2021.

SOROKA, T. Scribing as a modern form of visualization of educational material. Kharkiv: Osnova, 2015, 16/18, p. 60-62. (In Ukrainian). Available at :

http://journal.osnova.com.ua/article/51806. Access: June 21, 2021.

SUHROH, F.; CAHYONO, B. Y.; ASTUTI, U. P. Effect of Using Whiteboard Animation in Project-Based Learning on Indonesian EFL Students' English Presentation Skills across Creativity Levels. Arab World English Journal, 2020, p. 212-227. Available at : 
https://doi.org/10.24093/awej/call6.14. Access: June 21, 2021.

VETROVA, E. A.; KABANOVA, E. E.; MEDVEDEVA, N. V.; JUKOVA, E. E. Management of Educational Services Promotion in the Field of Higher Education (the Example of "Russian State Social University"). European Journal of Contemporary Education, 2019, 8 (2), p. 370 377. Available at : https://doi.org/10.13187/ejced.2019.2.370. Access: June 21, 2021.

VIDEOSCRIBE. 2020. Retrieved from: https://www.videoscribe.co. Access: June 21, 2021.

YARMOSHCHUK, O.; VASYLIUK, $V$. The use of mnemonics as an active method of teaching in classes with students majoring in "Physical Education". Innovation in Education, 2016, 3, p. 182-189. http://nbuv.gov.ua/UJRN/inuv_2016_3_23. Access: June 21, 2021.

YARMOSHCHUK, O.; VASILYUK, V.; DEMCHUK, O.. Use of scribing as an active method of training in classes with students in the specialty «Physical education»). Topical Issues of Pedagogy, Psychology and Professional Education, 2017, No 5, (In Ukrainian). Available at : http://journals.uran.ua/apppfo. Access: June 21, 2021.

ZAMIRALOVA, T. A.; SIZIKOVA, V. V.; KARPUNINA, A. V.; SHIMANOVSKAYA, Y. V.; KVITKOVSKAYA, A. A. Influence of university advertising activities on competitiveness in the educational services market. lioab Journal, 2020, 11, p. 49-51.

ZHANG, Z. L.; LI, Z. F.; LIU, H.; SHU, J. B.; ATLANTIS, P. Research on the Knowledge Visualization teaching based on the Double-Whiteboard. In Proceedings of the 2017 international conference on advanced technologies enhancing education, 2017, Vol. 68, p. 73-77. Available at : https://www.researchgate.net/publication/312866500_Research_on_ the_Knowledge_Visualization_Teaching_Based_on_the_Double-Whiteboard. Access: June $21,2021$. 
Video scribing as a new marketing tool for educational institutions

\section{Vídeo descritor como uma nova ferramenta de marketing para instituições de ensino}

\section{Video descriptor como una nueva herramienta de marketing para instituciones educativas}

\section{Resumo}

Este artigo tem como objetivo examinar a assinatura de vídeo como uma nova ferramenta de marketing que pode efetivamente influenciar um público-alvo através da visualização de informações usando os programas educacionais da Universidade Borys Grinchenko Kyiv como exemplo. A base empírica da pesquisa incluiu 27 vídeos de escribas compartilhados nas plataformas oficiais de mídia social da Universidade Borys Grinchenko Kyiv entre 2017 e 2020. Os dados coletados incluíram análises estáticas na web para eficácia e interação do público, como demonstrado por sua observação e gosto de uma série de vídeos escribas. O número total de visualizações de vídeos de escribas nas redes sociais foi de aproximadamente 68.000 . Esse total sugere que a tecnologia de assinatura de vídeo é uma ferramenta eficaz para incorporar na estratégia de marketing da Universidade Borys Grinchenko Kyiv. Esta pesquisa experimental, baseada na implementação da tecnologia de videografo (a implementação, neste caso, fez parte da estratégia de marketing da Universidade Borys Grinchenko Kyiv), abre amplas oportunidades para a promoção de programas e projetos educacionais através desse tipo de comunicação visual para outras instituições de ensino superior.

Palavras-chave: Visualização. Estratégia. Inovação. Tecnologia. Educação.

\section{Abstract}

This article aims to examine video scribing as a new marketing tool that can effectively influence a target audience through information visualization using the educational programs of Borys Grinchenko Kyiv University as an example. The empirical basis for the research comprised 27 scribe videos shared on the official social media platforms of Borys Grinchenko Kyiv University between 2017 and 2020. Data collected included static web analysis for effectiveness and audience interaction as demonstrated by their watching and liking of a scribe video series. The total number of scribe video views on social media was approximately 68,000 . This total suggests that video scribing technology is an effective tool to incorporate into Borys Grinchenko Kyiv University's marketing strategy. This experimental research, based on the implementation of video scribing technology (the implementation, in this case, was a part of Borys Grinchenko Kyiv University's marketing strategy), opens wide further opportunities for the promotion of educational programs and projects through this type of visual communication for other institutions of higher education.

Keywords: Visualization. Strategy. Innovation. Technology. Education.

\section{Resumen}

Este artículo tiene como objetivo examinar la escritura de vídeo como una nueva herramienta de marketing que puede influir eficazmente en un público objetivo a través de la visualización de la información utilizando los programas educativos de la Universidad Borys Grinchenko Kyiv como ejemplo. La base empírica de la investigación consistió en 27 videos de escribas compartidos en las plataformas de redes sociales oficiales de la Universidad Borys Grinchenko Kyiv entre 2017 y 2020 Los datos recopilados incluyeron análisis web estáticos para la efectividad y la interacción de la audiencia, como lo demuestra su observación y gusto por una serie de videos de escribas. El número total de reproducciones de video en las redes sociales fue de aproximadamente 68,000. Este total sugiere que la tecnología de escritura de video es una herramienta efectiva para incorporar en la estrategia de marketing de la Universidad Borys Grinchenko Kyiv. Esta investigación experimental, basada en la implementación de la tecnología de video scribing (la

implementación, en este caso, fue parte de la estrategia de marketing de la Universidad Borys Grinchenko Kyiv), abre amplias oportunidades adicionales para la promoción de programas y proyectos educativos a través de este tipo de comunicación visual para otras instituciones de educación superior.

Palabras-clave: Visualización. Estrategia. Innovación. Tecnología. Educación. 